\title{
EVOLUȚIA RELAŢIILOR ECONOMICE DINTRE ROMÂNIA ŞI STATELE SUBSAHARIENE ÎNAINTE DE DECEMBRIE 1989 ŞI ÎN PRIMELE DOUĂ DECENII DE TRANZIŢIE
}

Dr. Iulia-Alba Catrinel POPESCU*

Decolonizarea Africii Subsahariene a reprezentat o oportunitate speculată inteligent de regimul comunist de la Bucureşti. Spre deosebire de celelalte state comuniste, inregimentate curentului ideologic impus de Moscova, România a promovat o politică externă independentă şi a căutat să stabilească relaţii economice cu toate statele în curs de dezvoltare, indiferent de orientarea lor politică. Dar evenimentele din decembrie 1989 au schimbat radical politica României faţă de statele subsahariene. Articolul de față propune o analiză a modului în care au evoluat relatiile economice dintre România şi statele subsahariene înainte de evenimentele din decembrie 1989 şi în primele două decenii ale tranziţiei spre economia de piaţă.

Cuvinte-cheie: Africa Subsahariană; G 77; Parteneriatul Strategic UE-Africa; Decembrie 1989; Direcţia Orientul Mijlociu şi Africa.

Timp de 21 de ani, între anii 1968 şi 1989, România a fost unul dintre principalii parteneri economici ai statelor subsahariene. Intuind oportunitatea oferită de decolonizare, regimul comunist de la Bucureşti a devenit cel mai vocal

* Dr. Alba-Iulia Catrinel POPESCU este conferențiar universitar în cadrul Colegiului Național de Apărare, din Universitatea Națională de Apărare „Carol I”, București. E-mail: albapopescu1@gmail.com 
şi mai vizibil partener al noilor state postcoloniale, indiferent de orientarea lor politică. Însă, relaţiile economice ale României cu spaţiul subsaharian au fost influenţate radical de schimbările politice, geopolitice, sociale şi ideologice subsecvente evenimentelor din decembrie 1989.

În paginile următoare vom trece în revistă principalele domenii de cooperare economică dintre România şi partenerii săi subsaharieni şi cum au evoluat aceste relaţii economice înainte şi după evenimentele din decembrie 1989, în primele două decenii ale tranziţiei spre economia de piaţă.

\section{Perioada Războiului Rece}

Statele africane subsahariene s-au confruntat încă de la obţinerea independenţei cu mari dezechilibre structurale ale economiilor, traduse prin dualismul generat de coexistenţa practicilor economice arhaice de tip barter cu cele moderne, precum şi de fracturarea sistemului economic din cauza corelaţiilor minimale sau inexistente între sectoarele economiilor naţionale. Aceste dezechilibre, asociate cu subdezvoltarea consecutivă anilor de colonialism, lipsa de experienţă a liderilor şi cu mizele jucătorilor geostrategici activi pe continentul african au contribuit din plin la eşecul actual al industrializării statelor africane şi, în unele cazuri, chiar la faliment statal.

Devenite pieţe de desfacere ale bunurilor de consum şi exportatoare de materii prime brute, statele africane au înregistrat deficite comerciale, care s-au adâncit odată cu trecerea timpului. La această stare de fapt au contribuit:

- dezechilibrul economic generat de investițiile directe occidentale care au vizat cu precădere serviciile publice şi sectorul extractiv;

- repatrierea integrală a profiturilor de către investitori;

- sistemul de creditare neavantajos acordat de instituțiile financiare internaţionale statelor africane, având în vedere factorii de risc asociaţi acestor tinere democraţii;

- crizele economice de la sfârşitul anilor 1970 şi începutul anilor 1980, care au scăzut interesul eventualilor investitori occidentali pentru economiile africane.

Chiar dacă sistemul occidental de creditare din anii 1970, ceva mai flexibil în privinţa criteriilor de bonitate, a permis finanţarea unor proiecte de dezvoltare a statelor subsahariene, în anii 1980, când a venit scadenţa plăţilor, beneficiarele creditelor s-au văzut în imposibilitate de plată şi au intrat în recesiune.

În acest context economic, statele „lumii a treia” au pus bazele Grupului celor 77 (G77), România fiind singurul stat din Tratatul de la Varşovia ${ }^{1}$ care a devenit

${ }^{1}$ N.A.: Tratatul de prietenie, cooperare și asistență mutuală, fondat în data de 14 mai 1955, în capitala Poloniei, a fost o alianță militară a țărilor din Uniunea Sovietică (URSS) și din Blocul Răsăritean, 
membru al acestui for (dobândind şi statutul de observator în cadrul Mişcării de Nealiniere), ca urmare a sprijinului politico-diplomatic acordat, în instituţiile internaţionale, mişcărilor de eliberare naţională şi, mai apoi, statelor în curs de dezvoltare. Ca şi în cazul relaţiilor politico-diplomatice, perioada de după 1968 poate fi considerată perioada de deschidere şi de înflorire a relaţiilor economice ale ţării noastre cu statele africane.

În acest sens, începând cu 1968, între România şi statele subsahariene au fost semnate acorduri de cooperare economică şi tehnico-ştiinţifică, acorduri bilaterale comerciale şi de plăţi, protocoale şi contracte de cooperare economică, a căror derulare era analizată anual, în cadrul reuniunilor comisiilor mixte interguvernamentale ${ }^{2}$.

În 1973, au avut loc primele vizite la cel mai înalt nivel, ale unei delegaţii guvernamentale româneşti în Senegal şi Maroc ${ }^{3}$ iar, după 1974 relaţiile comerciale cu statele africane au dobândit o pondere deosebită. Prezenţa economică a României în statele subsahariene a consolidat relaţiile politico-diplomatice şi invers, existând o relaţie de potenţare reciprocă între cele două categorii de schimburi şi relaţii bilaterale. Motivaţia orientării ţării noastre către pieţele de desfacere ale statelor „lumii a treia” a fost una extrem de pragmatică şi de realistă: aceste piețe, care reprezentau peste trei sferturi din populaţia globului, deşi extrem de sensibile în privinţa costurilor de desfacere, erau mai puţin sensibile în privinţa calităţii şi a inovaţiei, putând oferi, la schimb, materii prime ieftine.

România a obţinut licenţe avantajoase de pescuit oceanic în apele teritoriale ale Mauritaniei şi Namibiei în baza cărora şi-a dezvoltat flota de pescuit şi industria conexă de conserve şi produse piscicole ${ }^{4}$. De asemenea, România a primit de la partenerii subsaharieni drept de exploatare a unor zăcăminte energetice şi minerale, la schimb cu investiţii în infrastructura de transport, export de armament ${ }^{5}$ şi cooperare

îndreptată împotriva Blocului Occidental condus de Statele Unite ale Americii (SUA). Şi-a încetat oficial existenţa la data de 1 iulie 1991, la Praga. Vezi: Petre Opriş, România în Organizaţia Tratatului de la Varşovia (1955-1991), Editura Militară, Bucureşti, 2008.

${ }^{2}$ Gheorghe Zaman, George Georgescu, A retrospective study on Romania's external trade in the past 100 year, Munich Personal RePEc Archive, octombrie 2018, p. 22, URL: https://mpra.ub.unimuenchen.de/89707/1/MPRA_paper_89707.pdf, accesat la 10.07.2021.

3 ***, Politica externă - repere cronologice III (1971-1980), Comunismul in România, 11 martie 2015, URL: https://www.comunismulinromania.ro/index.php/politica-externa-repere-cronologiceiii-1971-1980/, accesat la 10.07.2021.

${ }^{4}$ Nicolae Zărnescu, ,Întreprinderea de Pescuit Oceanic - unicat al industriei alimentare din economia socialistă”, Linia Întâi, 23.10.2013, URL : http://linia1.ro/intreprinderea-de-pescuit-oceanic-unicatal-industriei-alimentare-din-economia-socialista/, accesat la 11.07.2021.

5 ***, „Peştii, armele şi spionii. Ce legătură este între flota românească de pescuit, războaiele din Africa şi căderea lui Ceauşescu", ProTV, 28.09.2014, URL: http://stirileprotv.ro/emisiuni/2014/ sezonul-2/pestii-armele-si-spionii-ce-legatura-este-intre-flota-romaneasca-de-pescuit-razboaieledin-africa-si-caderea-lui-ceausescu.html, accesat la 23.06.2021. 
în domeniul educaţiei ${ }^{6}$. Pentru a-şi permanentiza prezenţa pe piețele subsahariene şi pentru a exploata resursele minerale şi energetice oferite de partenerii africani, România a constituit societăți mixte, precum Carombois şi Lorombois în Republica Centrafricană, Nirowi în Nigeria, Socaton - SAPM (Romagrimex) în Republica Congo, ZAIROM în Zair, Besaminco în Tanzania ${ }^{7}$ şi Simar, creată în parteneriat cu agenți economici din Mauritania ${ }^{8}$.

Întreprinderi precum Tractorul Braşov, Semănătoarea Bucureşti, Progresul Brăila, ARO Câmpulung, Dacia Piteşti, Romcim, Rompetrol, Arcom, Geomin, Uzinexportimport, Oltchim Râmnicu Vâlcea, Azomureş au devenit binecunoscute în spaţiul african, produsele româneşti fiind apreciate de beneficiari până în prezent. După cum afirmă, într-un studiu, ambasadorul Marcel Dinu', în Burundi, un geolog român a descoperit unul dintre cele mai însemnate zăcăminte de nichel din lume, în Nigeria, specialiştii români au acordat asistenţă tehnică companiei naţionale de petrol Nigerian Naţional Petroleum Corporation (N.N.P.C.) iar, în Angola, în 1985, specialiştii români au construit depozitele petroliere din oraşul Huambo, în valoare de circa 10 milioane dolari SUA ${ }^{10}$. Acestora li s-au adăugat şi alte proiecte de anvergură, duse la bun sfârşit de companiile româneşti, precum:

- clădirea Parlamentului sudanez din Khartoum ${ }^{11}$ şi alte construcţii civile în Nigeria, Ghana, Camerun etc.;

- exploatări petroliere şi miniere în Nigeria, Zambia, Kenya, Burundi, Senegal, Guineea;

- construcţia de infrastructură de transport rutier în Nigeria, Ghana;

- construcţia de infrastructură de transport aeroportuar în Mozambic, Senegal;

\footnotetext{
${ }^{6}$ Ilarion Ţiu, „Republica Africa Centrală, la picioarele lui Ceauşescu”, Historia, URL: https://www.historia.ro/sectiune/general/articol/republica-africa-centrala-la-picioarele-lui-ceausescu, accesat la 23.06.2021 7 ***, Raport privind creanțele României la 31 iunie 2005, provenite din activitatea de export, cooperarea economică internațională și alte acțiuni externe, derulate înainte de 31 decembrie 1989 , Ministerul Finanțelor Publice, 28.06.2006, URL: http://www.cdep.ro/bperm/2006/F26954-creante. pdf, accesat la 23.06.2021.

8 ***, ACORD din 24 septembrie 1987 intre Guvernul Republicii Socialiste România şi Guvernul Republicii Islamice Mauritania privind cooperarea în domeniul pescuitului maritim şi activităţile conexe, URL: http://legislatie.just.ro/Public/DetaliiDocumentAfis/22686?fbclid=IwAR2Hm6CD17 AWVyBf3i3cQUgmp8WEWI7MNi9GXzcmUt8KRT08r_mJEpWz7QU, accesat la 10.07.2021.

${ }_{9}^{9}$ Marcel Dinu, „Unele considerente referitoare la extinderea relaţiilor României cu statele din Africa, Asia, America Latină şi Orientul Mijlociu în a doua jumătate a secolului XX”, URL: http://www. irsea.ro/Rela--355-ii-externe-secolul-XX/, accesat la 23.11.2014.

10 ***, Relaţii bilaterale Republica Angola, Direcţia Orientul Mijlociu şi Africa din Ministerul Afacerilor Externe, URL: http://www.mae.ro/bilateral-relations/1809\#699, accesat la 23.11.2014.

11 ***, ,Pe urma miliardelor pierdute ale României socialiste, investite în afară”, Romania Military, 26.04.2012, URL: http://www.rumaniamilitary.ro/pe-urma-miliardelor-pierdute-ale-romanieisocialiste-investite-in-afara, accesat la 23.04.2017.
} 
- dezvoltare de culturi agricole în Mozambic, Republica Centrafricană, Congo şi Zair - R.D. Congo;

- foraje de apă potabilă în Zambia ${ }^{12}$.

Memorialistul primei expediţii româneşti panafricane, biologul Nicolae Coman, a povestit că, în cursul călătoriei parcurse la volanul automobilului de teren ARO, fabricat la Câmpulung Muscel, membrii expediţiei au fost surprinşi de notorietatea României în statele pe care le parcurgeau şi de numărul impresionant de africani care dezvoltaseră fie legături economice, fie de natură educaţională cu ţara noastră. Printre multele întâlniri surprinzătoare cu românii stabiliţi în Africa sau cu africanii educaţi în România, Coman şi-a amintit de întrevederea cu reprezentanţii Asociaţiei de Prietenie Sudan-România, care număra 10.000 de membri, sau de întâlnirile cu localnicii din Burundi, absolvenţi ai facultăţilor de medicină, geologie şi construcţii din România care, la acea oră, ocupau funcţii de conducere guvernamentale ${ }^{13}$.

În anii 1980, în contextul izolării internaţionale la care era supus regimul comunist de la Bucureşti, atât de occidentali, cât şi de „statele frăţeşti” din blocul sovietic, piaţa africană a devenit una dintre ţintele predilecte ale întreprinderilor de comerţ exterior româneşti. Chiar dacă au existat şi numeroase contracte păguboase, semnate exclusiv din rațiuni ideologice, de întrajutorare a „̧̧̆rilor frățești”, sau din rațiuni legate de cultul personalității președintelui Nicolae Ceaușescu (1918-1989), care dorea să îşi demonstreze anvergura de lider politic mondial, per ansamblu balanţa comercială a fost în favoarea țării noastre, iar relațiile bilaterale au servit intereselor economice şi politice ale României.

Principalele produse importate de România din statele africane subsahariene au fost materii prime nealimentare (ţiţei, bauxită şi alte minereuri neferoase, bumbac etc.), iar principalele produse românești exportate în Africa Subsahariană au fost alimente, produse chimice, maşini, utilaje, materiale de construcţii etc. ${ }^{14}$

12 ***, Tradiţia relaţiilor româno-africane, Direcţia Orientul Mijlociu şi Africa din cadrul Ministerului Afacerilor Externe, Bucureşti, 2009, p. 2.

${ }^{13}$ Nicolae Coman, De la Atlantic la Oceanul Indian. Insemnările unui biolog din prima expediţie românească trans-africană (1970-1971), Editura Dacia, Cluj-Napoca, 1975, pp. 10-30.

${ }^{14}$ Gheorghe Zaman, George Georgescu, op.cit., p. 29. 


\section{ISTORIE MILITARĂ}

Tabelul nr. 1: Volumul tranzacţiilor comerciale ale României cu state africane (milioane de lei valută la cursul anului respectiv) ${ }^{15}$

\begin{tabular}{|c|c|c|c|c|c|}
\hline \multirow{4}{*}{ Angola } & Anul & 1980 & 1985 & 1987 & 1989 \\
\cline { 2 - 6 } & Export & 82,7 & 117,6 & 27,5 & 64,7 \\
\cline { 2 - 6 } & Import & 203,7 & 1,8 & - & - \\
\hline \multirow{3}{*}{$\begin{array}{c}\text { Coasta de } \\
\text { Fildes }\end{array}$} & Anul & 1970 & 1980 & 1985 & 1987 \\
\cline { 2 - 6 } & Export & 0,9 & 23,8 & 7,2 & 68,7 \\
\cline { 2 - 6 } & Import & - & 46,2 & 83,9 & 2,9 \\
\hline \multirow{3}{*}{ Etiopia } & Anul & 1970 & 1980 & 1987 & 1989 \\
\cline { 2 - 6 } & Export & 0,7 & 19,4 & 97,6 & 24,6 \\
\cline { 2 - 6 } & Import & - & 23,2 & 36,4 & 48,8 \\
\hline \multirow{3}{*}{ Guineea } & Anul & 1970 & 1980 & 1985 & 1989 \\
\cline { 2 - 6 } & Export & 3,1 & 2,4 & 84,7 & 29,5 \\
\cline { 2 - 6 } & Import & 3,7 & 31,2 & 151,6 & 26,0 \\
\cline { 2 - 6 } & Anul & 1970 & 1980 & 1985 & 1989 \\
\cline { 2 - 6 } & Export & 2,0 & 0 & 43,5 & 2,8 \\
\hline \multirow{3}{*}{ Nigeria } & Import & 3,0 & - & 112,6 & 7,5 \\
\cline { 2 - 6 } & Anul & 1970 & 1980 & 1985 & 1989 \\
\cline { 2 - 6 } & Export & 16,3 & $1.399,5$ & $1.384,5$ & 729,6 \\
\hline \multirow{3}{*}{ Sudan } & Import & - & 160,9 & - & 1,2 \\
\cline { 2 - 6 } & Anul & 1960 & 1970 & 1985 & 1989 \\
\cline { 2 - 6 } & Export & 9,5 & 24,7 & $1.028,6$ & 107,6 \\
\cline { 2 - 6 } & Import & 4,81 & 13,6 & 391,1 & 9,6 \\
\hline \multirow{3}{*}{ Tanzania } & Anul & 1970 & 1985 & 1987 & 1989 \\
\cline { 2 - 6 } & Export & 0,5 & 17,2 & 219,4 & 157,2 \\
\cline { 2 - 6 } & Import & - & 1,0 & 157,8 & 62,8 \\
\hline \multirow{2}{*}{$\begin{array}{c}\text { Zair } \\
\text { (actuala }\end{array}$} & Anul & 1980 & 1985 & 1987 & 1989 \\
\cline { 2 - 6 } R.D.Congo) & Export & 3,0 & 21,2 & 61,6 & 22,0 \\
\cline { 2 - 6 } & Import & 147,3 & - & 26,2 & 2,6 \\
\hline
\end{tabular}

Conform datelor oferite de Anuarul statistic al României ${ }^{16}$ (a se vedea Tabelul nr. 1), în anul $1985 \mathrm{~s}-\mathrm{a}$ atins nivelul maxim al tranzacţiilor comerciale dintre România şi o serie de state subsahariene, foarte ofertante sub aspectul resurselor şi al mărimii pieţei de desfacere, precum: Angola, Ghana, Guineea, Nigeria, Sudan, Tanzania, Zair (actuala R.D. Congo). În cazul Etiopiei şi al Coastei de Fildeş, volumul maxim al tranzacţiilor comerciale bilaterale a fost atins în anul 1987.

$15 * * *$, Anuarul Statistic al României 1980-1989, apud Nicolae Melinescu, Uriaşul care se trezeşte, CA Publishing, Bucureşti, Cluj-Napoca, 2009, vol. 2, pp. 91-92.

${ }^{16}$ Ibidem. 
Analizând dinamica tranzacţiilor comerciale cu Nigeria şi Sudan, constatăm că, în anul 1980, România a importat un volum de mărfuri în valoare de 1.399,5 milioane lei valută din Nigeria, iar în 1985, a importat un volum de mărfuri în valoare de 1.028,6 milioane lei valută din Sudan. În anii 1970 şi 1985, volumul importurilor româneşti din Nigeria era zero. Explicaţia acestei creşteri masive a importurilor româneşti din cele două state africane este legată de Revoluţia Islamică din Iran, din 1979, care a determinat reorientarea regimului de la Bucureşti către alte surse de ţiţei. În anul 1985, în Nigeria a avut loc un puci, prin care generalul Muhammadu Buhari a fost înlăturat de la putere şi în locul acestuia s-a instalat generalul Ibrahim Babangida. Instabilitatea generată de criza politică nigeriană s-a reflectat în volumul tranzacțiilor comerciale.

Coroborând dinamica activităţii diplomatice a regimului de la Bucureşti în spaţiul amintit cu datele ilustrate în tabelul din Figura 1, reiese legătura strânsă dintre factorul politic şi cel economic în cadrul relaţiilor bilaterale dintre România şi statele subsahariene, traseul ascendent din perioada anilor 1970 şi ai primei jumătăţi din anii 1980, precum şi orientarea statului român către acele economii africane atractive sub aspectul materiilor prime energetice şi minerale.

\section{Perioada premergătoare aderării României la UE}

Restructurarea economică a României din anii 1990, prin dezindustrializare şi schimbarea priorităţilor de politică externă, a trecut în plan secund relaţiile economice cu statele africane, cu atât mai mult cu cât acestea, la rândul lor, au trecut prin intense perioade de transformări interne, pe fondul schimbării jucătorilor geostrategici locali. Pe cale de consecinţă, începând cu anul 2014, în spaţiul subsaharian mai funcţionează doar şapte din cele 28 de ambasade româneşti deschise înainte de 1989, la care s-a adăugat ambasada din Africa de Sud, deschisă la data de 21 noiembrie 1991. Activitatea acestor ambasade ale României din Nigeria, Africa de Sud, Angola, Sudan, Senegal, Kenya, Etiopia, Zimbabwe este completată pe linie consulară de 16 consulate onorifice, deschise în state unde există cetăţeni români: Nigeria (4 consulate), Benin, Guineea, Guineea Bissau, Mali, Mauritania, Mozambic, Niger, Senegal, Africa de Sud, Republica Centrafricană, Coasta de Fildeş, Republica Congo. Cu toate acestea, închiderea a 20 de ambasade s-a răsfrânt atât asupra capitalului de influență românesc în spaţiul subsaharian, cât şi asupra relaţ̧iilor economice şi militare ${ }^{17}$ dezvoltate cu statele subsahariene. Prin dezangajare diplomatică au fost pierdute licenţe importante, precum cele de pescuit oceanic sau de exploatare ale zăcămintelor energetice şi minerale,

\footnotetext{
${ }^{17}$ Informații despre subiect pot fi găsite în: Alba-Iulia Catrinel Popescu, „Aspecte cu privire la evoluţia relaţiilor militare dintre România şi statele subsahariene înainte şi după evenimentele din decembrie 1989”, Buletinul Universităţii Naţionale de Apărare „, Carol I”, vol. 4, nr. 2/2017, Editura Universităţii Naţionale de Apărare „Carol I”, pp. 17 - 26.
} 
produsele româneşti au dispărut treptat de pe piaţa subsahariană -ocupată de foştii competitori din spaţiul estic sau vestic, iar creanţele României în Africa Subsahariană, în valoare de miliarde de dolari (SUA) şi ruble convertibile, au fost fie preluate la preț de nimic de diverse companii, unele cu adrese de contact prin off-shore-uri ${ }^{18}$, fie au fost șterse prin hotărâri de guvern.

Conform unui raport emis de Ministerul Finanţelor Publice, în 30 iunie 2005, volumul total al creanţelor României, rezultate din activitatea de export şi din alte acțiuni externe derulate înainte de 31 decembrie 1989, era de 2,2114 miliarde de dolari pe relaţia devize convertibile şi 1050,8 milioane de ruble transferabile. Din aceste sume, Sudanul datora 169,85 milioane de dolari si 881325 de lire sterline, Mozambicul 165,3 milioane de dolari, Nigeria 12,58 milioane de dolari ${ }^{19}$.

În 2007, volumul total al creanţelor României scăzuse 1,427 miliarde de dolari şi 1,099 miliarde de ruble transferabile.

$\mathrm{Cu}$ o generozitate demnă de marile economii mondiale, guvernele care au condus România în primul deceniu al mileniului trei au şters sau au diminuat aceste datorii prin tratate şi înţelegeri internaţionale de tipul Clubului de la Paris ${ }^{20}$. Spre exemplu Mozambicul, ţară bogată în minereuri strategice, care datora României 135 milioane de dolari şi al cărei guvern era dispus să plătească prin proprietăți miniere, nu doar că nu a mai cedat nici o proprietate statului român, ci a rămas şi cu o datorie diminuată de numai 12,4 milioane de dolari ${ }^{21}$. Guineea, statul subsaharian care deţine peste $33 \%$ din rezervele mondiale de bauxită ${ }^{22}$, avea o datorie de 20,67 milioane de dolari. Printr-o hotărâre de guvern, aceleaşi autorităţi de la Bucureşti au renunţat la peste $90 \%$ din datorie, diminuând-o la două milioane de dolari. Iar, în cazul datoriei de 10,6 milioane de dolari a Republicii Centrafricane, ţară bogata in minereuri neferoase, au luat decizia de scoatere a acesteia, prin lege, din evidenţa extra-bilanțieră a contabilității publice. Cinci ţări debitoare - Sudan, Republica Congo, Nigeria, Somalia, Tanzania - cumulau datorii de peste 190 milioane de dolari, dintre care aproximativ 170 de milioane de dolari reprezentau doar datoria Sudanului, stat bogat în hidrocarburi şi

$18 * * *$, ,Pe urma miliardelor pierdute ale României socialiste, investite în afară”, Romania Military, op. cit.

19 ***, Raport privind creanţele României la 31 iunie 2005, provenite din activitatea de export, cooperarea economică internațională şi alte acțiuni externe, derulate înainte de 31 decembrie 1989 , op.cit.

${ }^{20}$ N.A.: Clubul de la Paris reprezintă un grup informal de creditori oficiali al cărui rol este de a găsi soluții coordonate și durabile la dificultățile de plată cu care se confruntă țările debitoare. Vezi URL: https://clubdeparis.org/, accesat la 23.08.2021.

${ }^{21}$ Daniel Ionaşcu, „Aici sunt banii dumneavoastră. Miliarde de dolari, risipite de România prin investiții în alte țări”, Libertatea, 01.07.2018, URL: https://www.libertatea.ro/stiri/aici-sunt-baniidumneavoastra-miliarde-de-dolari-risipite-de-romania-prin-investitii-alte-tari-2312134, accesat la 23.08.2021.

${ }^{22}$ Alba-Iulia Catrinel Popescu, Jucătorul din umbră, Editura Militară, Bucureşti, 2016, p. 60. 
minereuri neferoase. La momentul respectiv autorităţile române nu demaraseră nici un fel de negocieri pentru recuperarea acestor creanțe $e^{23}$. Doar R.D. Congo (Zair), al cărui subsol este bogat în diamante, cobalt, tantal şi alte minereuri strategice și aurifere ${ }^{24}$, avea o datorie reglementată la 595 de milioane de dolari.

Nici mai târziu sumele recunoscute de către statele debitoare nu au fost recuperate în totalitate de statul român. În 2019, volumul total al creanțelor nerecuperate era de 716 milioane de dolari şi 1,5 miliarde de ruble transferabile, dintre care 241,3 milioane de dolari $(33,70 \%)$ reprezentau creanţe nesoluţionate $\mathrm{cu}$ Sudan, Nigeria, Republica Centrafricană, Somalia, Tanzania şi Libia ${ }^{25}$.

Cauzele nerecuperării acestor creanțe de către statul român, așa cum rezultă din raportul mai sus-menționat sunt „dificultăţile majore de ordin economic, financiar şi valutar cu care se confruntă unele țări africane, ale căror debite către România însumează 376,4 milioane de dolari SUA (17\% din totalul creanțelor), calificate pentru a primi asistenţă conform HIPC (ţări cu grad înalt de îndatorare, cele mai sărace din lume): Sudan, Guineea, R. Centrafricană, R. Congo, R.D. Congo, Mozambic, Somalia, Tanzania" şi ,apartenenţa unor ţări debitoare, care fac parte deja din programul HIPC, la categoriile de ,ţări afectate de conflicte" şi ,țări post-conflicte" care urmează să primească sprijin financiar suplimentar din partea organismelor internaţionale: R. Centrafricană, R. Congo, R.D. Congo, Somalia, Sudan"26.

\section{Perioada primului deceniu de la aderarea României la UE}

Aderarea României la Uniunea Europeană la 1 ianuarie 2007 şi ajustarea politicilor româneşti la cele comunitare, între care se înscrie şi Parteneriatul Strategic UE-Africa ${ }^{27}$, au marcat o revenire economică a statului român în spaţiul african, chiar dacă mult mai redusă comparativ cu perioada anilor 1970-1980.

Cadrul legal al schimburilor comerciale româno-africane a fost asigurat, până la data aderării României la UE, de tratatele, acordurile, protocoalele şi înţelegerile

$23 * * *$, ,România are de recuperat creanțe de 1.472 mld. dolari, din 15 state”, Wall Street, 12.03.2007, URL: https://www.wall-street.ro/articol/Economie/26511/Romania-are-de-recuperat-creante-de-1472-mld-dolari-din-15-state.html, accesat la 23.08.2021.

${ }^{24}$ Alba-Iulia Catrinel Popescu, op.cit., pp. 90-107.

25 ***, ,Document: România are de încasat creanţe de 716 milioane dolari şi 1,5 miliarde ruble transferabile", Mediafax, 29.07.2019, URL: https://www.mediafax.ro/economic/document-romaniaare-de-incasat-creante-de-716-milioane-de-dolari-si-1-5-miliarde-de-ruble-transferabile-18252848, accesat la 23.08.2021.

26 ***, Raport privind creanțele României la 31 iunie 2005, provenite din activitatea de export, cooperarea economică internațională şi alte acțiuni externe, derulate înainte de 31 decembrie 1989, op.cit.

27 ***, The Africa-EU Partnership, URL: http://www.africa-eu-partnership.org/en/about-us/whatpartnership, accesat la 29.10.2015. 
semnate de statul român, înainte de 1989, cu statele africane. După ce țara noastră a devenit membră a comunității europene, aceste documente au devenit caduce, astfel că în prezent se desfăşoară procesul de actualizare a acestora.

Conform datelor oferite de Ministerul Afacerilor Externe (MAE) ${ }^{28}$, în perioada analizată, România a exportat în statele subsahariene îngrăşăminte chimice, mase plastice, kerosen, automobile Dacia Logan/Duster, tractoare şi piese de schimb, rulmenţi, aparate electrotehnice şi electrocasnice, anvelope auto, articole din hârtie, carton, lemn, sticlă, faianţă, ţesături şi tricotaje, materiale de construcţii (fier, oţel, fontă), sârmă, cereale, vin de masă.

În aceeaşi perioadă, importurile româneşti din statele africane au vizat în principal materii prime: petrol (Sudan), lemn de esență tropicală, cacao, pietre preţioase, cauciuc, bumbac, ceai, cafea, peşte şi crustacee, condimente, fructe, piei brute de ovine, bovine, caprine, minereu de mangan, bauxită (Guineea, Sierra Leone), fier (Republica Africa de Sud-R.A.S.), cărbune (R.A.S.).

\subsection{Schimburile comerciale dintre România şi Angola}

În prezent, relaţia economică româno-angoleză este normată de Protocolul de cooperare între ministerele de externe român şi angolez, semnat în $2008^{29}$.

Conform datelor furnizate de Direcţia Orientul Mijlociu şi Africa din cadrul M.A.E., exporturile româneşti în Angola au fost alcătuite în principal din îngrășăminte chimice, aparate electrotehnice, autoturisme Dacia-Logan.

În graficul din Figura nr. 1 se constată evoluţia oscilantă a schimburilor comerciale dintre România şi Angola, cu o revigorare a exporturilor în cursul anilor 2012 şi 2013 şi o scădere semnificativă în 2015. Este interesant de remarcat faptul că importurile româneşti din acest stat african sunt, practic, egale cu zero, în condiţiile în care Angola reprezintă unul dintre statele extrem de ofertante sub aspectul producţiei de hidrocarburi, metale preţioase, diamante, metale rare, uraniu etc.

Din păcate, după anul 2015 nu mai există raportări oficiale publice ale Ambasadei României din Angola privind dinamica schimburilor comerciale dintre cele două state.

${ }^{28}$ N.A.: Conform M.A.E., în cazul Republicii Africa de Sud (R.A.S.) ,aderarea României la U.E. a determinat renegocierea Acordului pentru Comerț, Dezvoltare şi Cooperare (T.D.C.A.) existent între U.E. şi R.A.S., prin introducerea României şi Bulgariei ca ţări care vor beneficia de facilităţile tarifare etc. oferite de acest cadru juridic. In baza procesului Aquis Communitaire, acordurile comerciale şi de cooperare economică au fost abrogate de comun acord, fiind înlocuite cu Acordul de Comert Dezvoltare şi Cooperare existent între U.E. şi R.A.S. (Trade Development Cooperation Agreement-T.D.C.A.)", în ***, Relaţii bilaterale Republica Africa de Sud, Direcţia Orientul Mijlociu şi Africa, Ministerul Afacerilor Externe, URL: http://www.mae.ro/bilateral-relations/1772\#746, accesat la 23.11.2014 şi în ***, Relații bilaterale, Ambasada României în Republica Africa de Sud, URL: https://pretoria.mae.ro/node/170, accesat la 12.09.2021.

$29 * * *$, „Republica Angola”, URL: https://www.mae.ro/bilateral-relations/1809, accesat la 23.07.2021. 


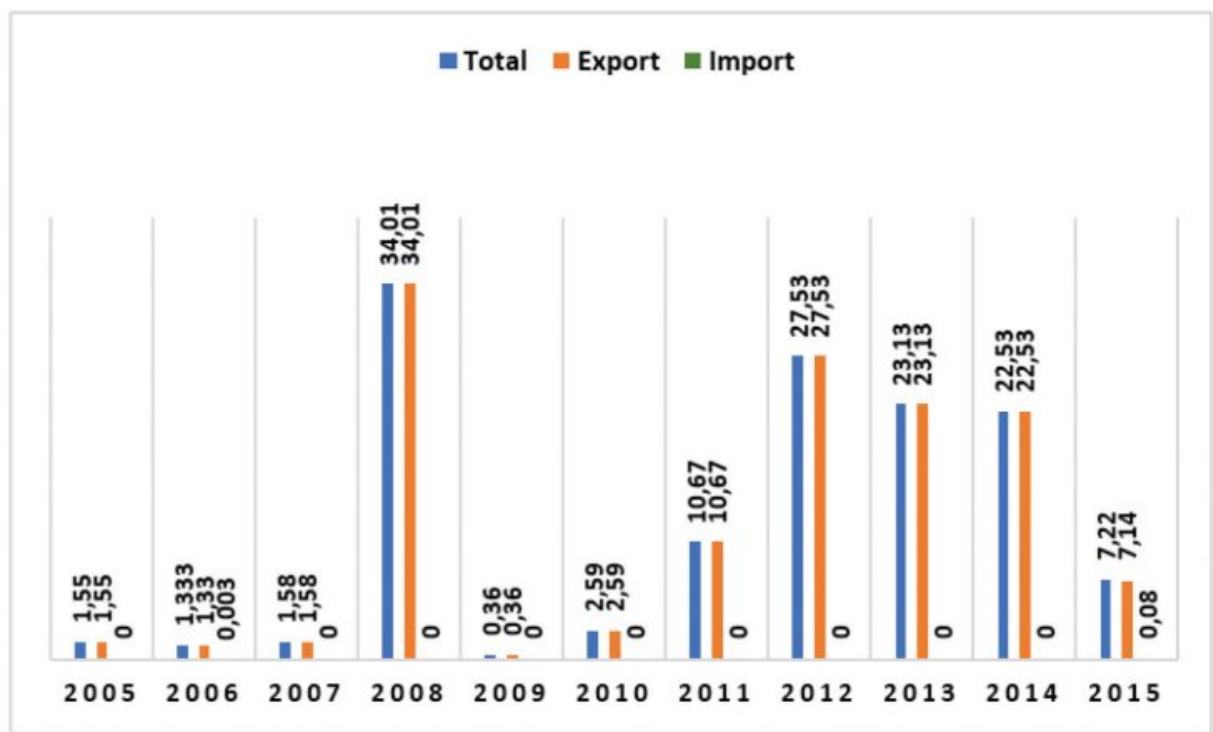

Figura nr. 1: Dinamica schimburilor comerciale România - Angola în perioada 2005-2015 (milioane de dolari) ${ }^{30}$

\subsection{Schimburile comerciale dintre România şi Republica Africa de Sud}

Conform M.A.E., până în anul 1990, România nu a întreţinut relaţii comerciale directe cu Africa de Sud, tranzacţiile comerciale derulându-se prin intermediari din terţe ţări.

La începutul anilor 1990, între cele două state s-au încheiat o serie de documente juridice, precum: Acord comercial (1990); Acord de cooperare economică (1993); Acord privind evitarea dublei impuneri (1993); Înţelegere privind desfiinţarea vizelor pentru paşapoartele diplomatice şi de serviciu (1995); Acord de cooperare între Camera de Comerţ şi Industrie a României şi Federaţia Camerelor de Comert din Republica Africa de Sud (1991); Memorandum privind statutul Comisiei mixte interguvernamentale de cooperare economică şi tehnică $(1994)^{31}$.

În graficul din Figura nr. 2 este prezentată dinamica schimburilor comerciale dintre România şi Africa de Sud în perioada 2006-2013. O primă observaţie este legată de excedentul comercial în creştere de partea română, ultimii patru ani ai perioadei de raportare înregistrând o creştere importantă a exporturilor. Altă observaţie se referă la accelerarea exporturilor româneşti începând cu anul 2008, după aderarea României la UE şi ajustarea politicii externe româneşti în acord cu cea europeană (parteneriatul strategic UE - Africa Subsahariană fiind un imperativ politic european).

30 ***, Relaţii economice, Ambasada României în Republica Angola, URL: https://luanda.mae.ro/ node/168, accesat la 23.07.2021.

31 ***, Republica AFRICA de SUD, Ministerul Afacerilor Externe, URL: https://www.mae.ro/ bilateral-relations/1772, accesat la 23.07.2021. 


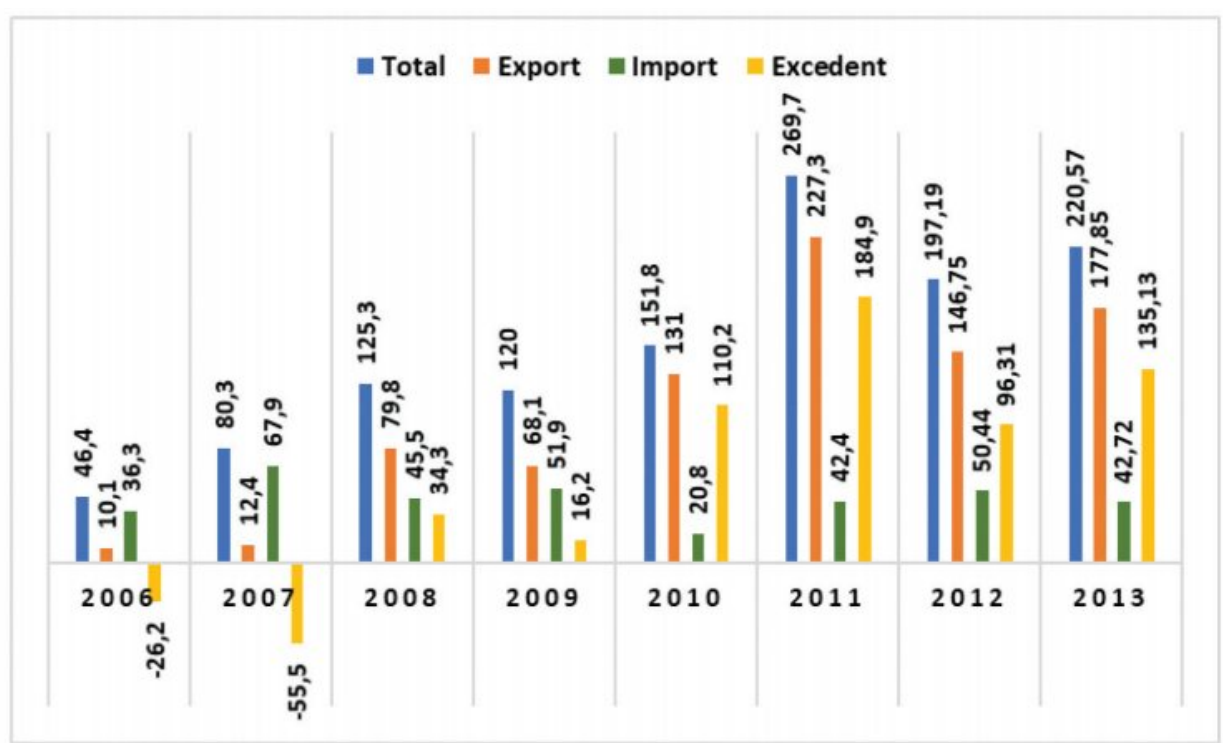

Figura nr. 2: Dinamica schimburilor comerciale România - Africa de Sud în perioada 2006-2013 (milioane de dolari) ${ }^{32}$

Conform M.A.E., exporturile româneşti în S.A.R. au fost alcătuite din: „nave, ciment, fibre poliester, produse chimice şi petrochimice, materiale plastice, produse de sticlărie, rezervoare de gaz, echipament de transmisie, produse ceramice, produse metalurgice, uree, mobilă, cauciucuri etc.", iar importurile din S.A.R. au vizat „fier, cărbune, vin, băuturi alcoolice, textile, maşini industriale, produse din aur semifinisate, lână, carne şi peşte, substanţe proteice, pompe, hârtie, tutun, azbest, piei, chimicale, sucuri de fructe etc." 33

În luna februarie 1996, compania sud-africană South African Breweries (S.A.B.) a preluat pachetul majoritar de acţiuni în valoare de 18 milioane de dolari de la fabrica de bere S.C. Vulturul Buzău S.A., fiind prima investiţie majoră de capital dintr-o ţară subsahariană în România. Ulterior, acţionarii sud-africani au investit alte 100 de milioane de dolari prin preluarea fabricii de bere Ursus din Cluj şi din Piteşti. La nivelul anului 2013, investiţiile sud-africane în ţara noastră depăşeau valoarea de 500 de milioane de euro, în domenii precum telecomunicaţiile (NASPERS), imobiliar (NEPL), subansamble auto (METAIR). Schimburile economice bilaterale sunt stimulate de vizitele anuale ale unor misiuni economice româneşti, precum şi de participările agenţilor economici din ambele state la târgurile internaţionale anuale organizate în România, precum Târgul Internaţional Bucureşti (T.I.B.) şi Târgul Internaţional de Bunuri de Larg Consum (T.I.B.C.O.) şi, în Africa de

32 ***, Relaţii bilaterale Republica Africa de Sud, Direcţia Orientul Mijlociu şi Africa, Ministerul Afacerilor Externe, URL: http://www.mae.ro/bilateral-relations/1772\#746, accesat la 23.11.2014. 33 ***, Relatii bilaterale Republica Africa de Sud, op.cit. 
Sud, The Southern African International Trade Exhibition for Retail Products (S.A.I.T.E.X.) - Târgul Internaţional Expoziţional Sud-African de Bunuri de Retail şi Africa Aerospace\&Defence, unde participarea românească se desfăşoară la nivel de pavilion naţional. Din păcate, după anul 2013 nu mai există raportări oficiale publice ale Ambasadei României din Africa de Sud privind dinamica schimburilor comerciale dintre cele două state ${ }^{34}$.

\subsection{Schimburile comerciale dintre România şi Etiopia}

Conform M.A.E., schimburile comerciale bilaterale, dintre România şi Republica Federală Democratică a Etiopiei sunt reglementate de acorduri de cooperare, precum:

- Convenţia între România şi R.F.D. Etiopia pentru evitarea dublei impuneri şi prevenirea evaziunii fiscale cu privire la impozitele pe venit şi pe capital, intrată în vigoare la 9 mai 2009;

- Protocolul de cooperare dintre Camera de Comerţ şi Industrie a României şi Camera de Comerţ şi Asociaţii Sectoriale a Etiopiei (E.C.C.S.A.), intrat în vigoare la 25 aprilie 1995.

Exporturile României în Etiopia au fost reprezentate de „cereale, produse chimice, materiale plastice, articole de lemn, hârtie şi carton, produse ceramice, sticlă şi articole din sticlă, materiale de construcţii (fontă, fier şi oţel), autoturisme DACIA, produse ale industriei aeronautice iar, importurile sunt constituite din cafea, ceai, condimente, piei brute şi prelucrate de bovine, ovine şi caprine”.

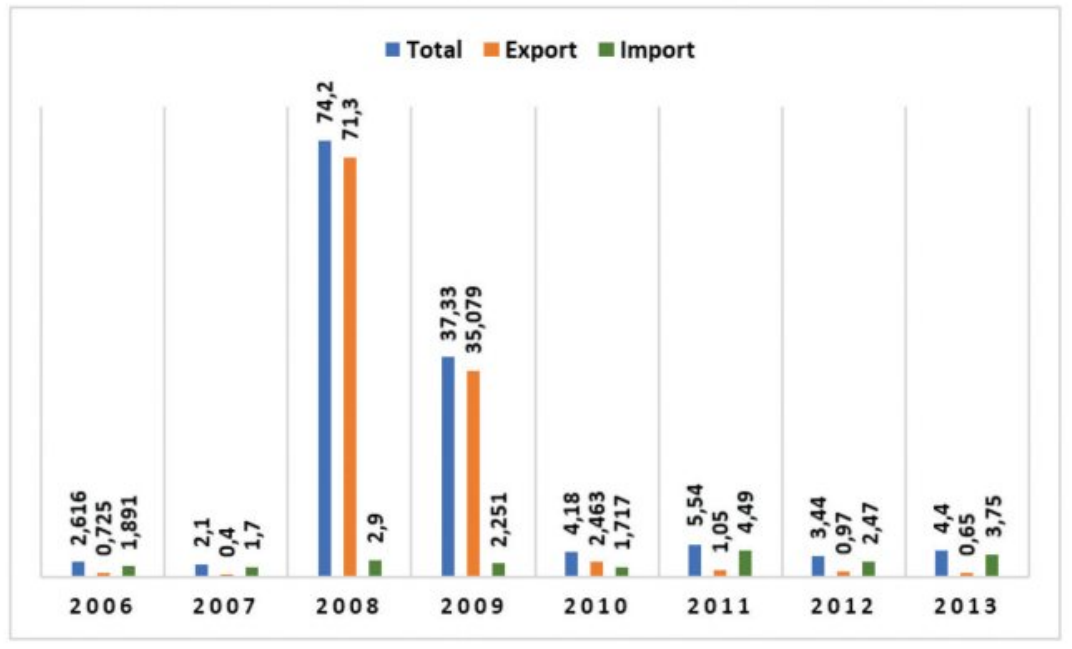

Figura nr. 3: Dinamica schimburilor comerciale România - Etiopia în perioada 2006-2013 (în milioane de dolari) ${ }^{35}$

34 Ibidem.

35 ***, Relații bilaterale Republica Federală Democratică a Etiopiei, Direcţia Orientul Mijlociu 
Valorile crescute ale exporturilor româneşti din cursul anilor 2008-2009 în graficul din Figura nr. 3 au legătură, în mare parte, cu situaţia producţiei agricole etiopiene, afectate de seceta prelungită şi epuizarea rezervelor naţionale de cereale. Situaţia rezervelor de hrană ale Etiopiei a fost agravată de imigraţia masivă dinspre Somalia a populaţiei afectate de conflicte şi de secetă.

\subsection{Schimburile comerciale dintre România şi Sudan}

Conform M.A.E., la 31 mai 2007, s-a semnat la Bucureşti Convenţia pentru evitarea dublei impuneri dintre România şi Sudan, în vigoare din noiembrie 2009. În iulie 2008, ,pentru a răspunde legislaţiei europene, s-a hotărât de comun acord încetarea valabilităţii a trei importante documente în domeniul economic: Acord de cooperare economică şi tehnică, Acord comercial şi Acord-Program pentru dezvoltarea pe termen lung a cooperării economice şi tehnice şi a schimburilor comerciale" ${ }^{\prime 6} . \mathrm{Cu}$ toate acestea, există şi alte acte normative din domeniul economic semnate înainte de 1989, aflate, încă, în vigoare, precum: Convenţia sanitar-veterinară între Guvernul R.S. România şi Guvernul R.D. Sudan (semnată la Khartoum, la data de 28.08.1974) şi Acordul între Guvernul R.S. România şi Guvernul R.D. Sudan privind serviciile aeriene între şi dincolo de teritoriile lor proprii (semnat la Bucureşti, la data de 13.05.1978 ${ }^{37}$ ).

România a exportat în Sudan produse ,alimentare, produse chimice, produse farmaceutice şi de parfumerie, articole din material plastic şi cauciuc, uleiuri minerale, produse metalurgice, produse din fontă (ţeavă de foraj petrolier), echipamente pentru căile ferate, piese de schimb pentru motoare cu combustie internă, lemn şi produse din lemn, hârtie, ciment, materiale textile" ${ }^{\prime 38}$. Aceeaşi sursă precizează că „Republica Sudan oferă oportunităţi de afaceri cu precădere în domeniile: petrolier, construcţii de maşini, agricol, industrie uşoară, energie electrică” şi că, ,sunt în curs negocieri pentru încheierea unor importante contracte în domeniul petrolier şi pentru construirea unei fabrici de ciment în Sudan"39.

În perioada 21-23 februarie 2012, în Khartoum, au avut loc lucrările Forumului Economic România - Sudan, organizat de către ministerul sudanez al petrolului, în coordonare cu Ambasada României, la care au participat „,reprezentanți a 27 de firme din România din domeniile petrolului, energiei electrice şi construcţiilor, precum

şi Africa din Ministerul Afacerilor Externe, URL: http://www.mae.ro/bilateral-relations/1854\#719, accesat la 23.11.2014.

36 ***, Cadru juridic bilateral, Ambasada României în Republica Sudan, URL: https://khartoum. mae.ro/node/170, accesat la 23.07.2021.

${ }^{37}$ Ibidem.

38 ***, Relaţii bilaterale Republica Sudan, Direcţia Orientul Mijlociu şi Africa, Ministerul Afacerilor Externe, URL: http://www.mae.ro/bilateral-relations/1767\#747, accesat la 23.11.2014.

${ }^{39}$ Ibidem. 
şi oficiali şi oameni de afaceri sudanezi" ${ }^{20}$. Dacă ne raportăm la datele incluse în graficul din Figura nr. 5, Forumul nu s-a soldat cu rezultate deosebite, în 2013 relaţiile economice suferind o contracţie pe seama importurilor provenite din Sudan deşi, în planul exporturilor româneşti pe piaţa sudaneză s-a înregistrat o creştere de circa 3 milioane de dolari.

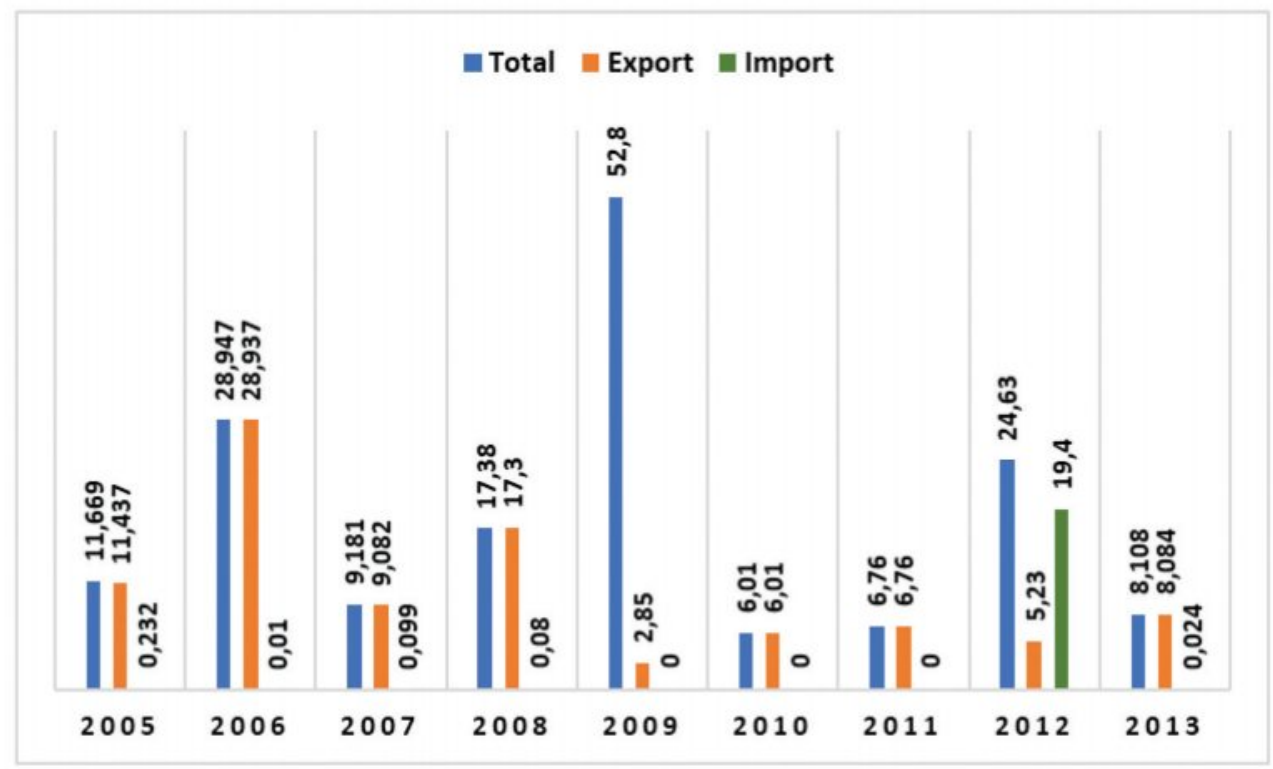

Figura nr. 4: Dinamica schimburilor comerciale România - Sudan în perioada 2005-2013 (în milioane de dolari) ${ }^{41}$

În graficul din Figura nr. 4 este ilustrată dinamica schimburilor comerciale dintre România şi Sudan în perioada 2005-2013, unde se constată o creştere marcantă a volumului importurilor româneşti la nivelul anului 2012, cel mai probabil secundară demersurilor diplomatice menţionate anterior. Deşi Sudanul este extrem de ofertant sub aspectul resurselor energetice şi minerale, instabilitatea politică precum şi izolarea diplomatică internaţională a regimului de la Khartoum se reflectă în volumul scăzut al schimburilor economice pe care România le-a dezvoltat, după 1989, cu acest stat african. Din păcate, după anul 2013 nu mai există raportări oficiale publice ale Ambasadei României din Sudan privind dinamica schimburilor comerciale dintre cele două state.

40 ***, Relatiii bilaterale - Scurt istoric, Ambasada României în Republica Sudan, URL: https:// khartoum.mae.ro/node/221, accesat la 12.09.2021.

41 ***, Relaţii bilaterale Republica Sudan, Direcţia Orientul Mijlociu şi Africa, Ministerul Afacerilor Externe, URL: http://www.mae.ro/bilateral-relations/1767\#747, accesat la 23.11.2014. 


\subsection{Schimburile comerciale dintre România și alte state subsahariene}

In Tabelul $n r .2$ este ilustrat volumul tranzacţiilor comerciale bilaterale dintre România şi 17 state africane subsahariene, la nivelul anului 2013.

\begin{tabular}{|c|c|c|c|}
\hline Statul & Volum total & Export & Import \\
\hline Burkina Faso & 7,10 & - & - \\
\hline Camerun & 6,426 & 5,686 & 0,74 \\
\hline Coasta de Fildeş & 10,216 & 9,019 & 0,197 \\
\hline Gabon & 10,44 & 10,42 & 0,02 \\
\hline Ghana & 6,715 & - & - \\
\hline Guineea & 26,13 & 1,11 & 25,02 \\
\hline Kenya & 25,38 & - & - \\
\hline Madagascar & 2,677 & 2,40 & 0,277 \\
\hline Mâli & 2,60 & 2,60 & - \\
\hline Mauritania & 30,00 & 28,5 & 1,50 \\
\hline Mauritius & 2,623 & 0,283 & 2,34 \\
\hline Mozambic & 7,43 & 5,23 & 2,20 \\
\hline Nigeria & 35,323 & - & - \\
\hline Senegal & 12,869 & 12,862 & 0,007 \\
\hline Sierra Leone & 25,809 & 0,932 & 24,977 \\
\hline Togo & 166,943 & 166,943 & - \\
\hline Zambia & 7,55 & 1,35 & 6,20 \\
\hline
\end{tabular}

Tabelul nr. 2: Volumul tranzacţiilor comerciale bilaterale dintre România şi statele africane subsahariene, în anul 2013 (în milioane de dolari) $)^{42}$

O primă observaţie este legată de volumul crescut al acestor schimburi comerciale cu state din Africa de Vest, comparativ cu statele din celelalte regiuni de dezvoltare subsahariene. Este remarcabil volumul exporturilor româneşti în Togo, un stat cu puţin peste 7,5 milioane de locuitori ${ }^{43}$, în timp ce volumul de doar 35,32 milioane de dolari al schimburilor economice cu Nigeria este unul infim, raportat la piaţa de desfacere de peste 177 de milioane de locuitori şi la potenţialul extrem de ofertant al economiei nigeriene. $\mathrm{Cu}$ excepţia unor state precum Guineea, Kenya, Mauritania şi Sierra Leone, unde schimburile comerciale bilaterale depăşesc 20 de milioane de dolari, în celelalte cazuri volumul tranzacţiilor comerciale fiind nesemnificativ.

Dacă analizăm nivelul importurilor româneşti şi coroborăm aceste date cu natura principalelor materii prime oferite de statele partenere, putem deduce nivelul

${ }^{42}$ Date prezentate pe internet de M.A.E., Direcţia Orientul Mijlociu şi Africa.

43 ***, ,TOGO”, CIA World Factbook, URL: https://www.cia.gov/library/publications/the-worldfactbook/geos/to.html, accesat la 29.10.2015. 
şi structura ramurilor industriale actuale ale economiei naţionale a României. De exemplu, singurele activităţi de import mai semnificative au fost desfăşurate în Guineea şi Sierra Leone, state bogate în bauxită, materie primă utilizată în industria aluminiului, încă funcţională în ţara noastră. În rest, state ofertante în privinţa minereurilor de cupru, cobalt, zinc şi fier, precum Zambia, sau deţinătoare de zăcăminte importante de hidrocarburi, uraniu, minereuri strategice, precum Nigeria, Mozambic, Madagascar, Gabon sunt aproape inexistente pe harta importurilor româneşti de materii prime, semn că ramurile industriale interne care ar fi putut fi interesate de astfel de produse nu mai există sau se aprovizionează din alte surse. Trebuie menţionat că relaţiile economice actuale ale României cu foste partenere comerciale precum Botswana, Burundi, R. Capului Verde, R. Centrafricană, Ciad, Djibouti, R.D. Congo, Congo, Guineea Bissau, Guineea Ecuatorială, Seychelles, Somalia sunt, de asemenea, nesemnificative, unele dintre aceste state africane fiind, astăzi, măcinate de conflicte civile (Somalia, R.D. Congo, Burundi, R. Centrafricană).

\section{Concluzii}

Apogeul relaţiilor României cu statele subsahariene a fost atins în perioada anilor 1980, pe fondul multiplelor parteneriate politice şi economice bilaterale, precum şi al izolării regimului de la Bucureşti atât de statele blocului occidental, cât şi de statele blocului comunist. În aceste condiţii, statele subsahariene, ca şi alte state sărace din Asia şi America Latină, au devenit principalii parteneri economici ai României comuniste. Relaţii bilaterale nu întotdeauna avantajoase economic pentru statul român, având în vedere că, în unele cazuri, erau profund ideologizate şi că serveau, totodată, unor nevoi propagandistice. Cu toate acestea, în perioada amintită, România a beneficiat de multiple avantaje economice din partea statelor „lumii a treia" - categorie care include şi statele subsahariene - exprimate prin preţuri scăzute de achiziţie a materiilor prime, licenţe avantajoase de exploatare a unor zăcăminte minerale şi energetice sau resurse piscicole.

La sfârşitul anilor 1980, România acumulase creanţe de ordinul miliardelor de dolari, care au fost pierdute, în mare parte, în anii premergători aderării ţării noastre la Uniunea Europeană. Pierderea acestor creanţe a fost rezultatul unui întreg şir de decizii politice dezastruoase, care au dus la dezangajare diplomatica regională şi la ştergerea unor mari părţi din datoriile acumulate de statele subsahariene, deşi o parte din aceste datorii puteau fi recuperate prin drepturi de concesiune şi exploatare a unor zăcăminte de minereuri sau câmpuri petrolifere, ori rambursarea lor putea fi amânată pentru o dată viitoare, când statul debitor putea plăti creanţele.

În aceiaşi ani premergători aderării ţării noastre la structurile comunitare, pe principiul că ,industria românească este un morman de fiare vechi”, s-a produs dezindustrializarea şi schimbarea radicală a profilului economic a României, de la 
o ţară în curs de industrializare, la o ţară furnizoare de servicii şi de materii prime brute şi o piaţă de desfacere pentru produse de import. În aceste condiţii, în absenţa nevoii de materii prime ieftine africane, prezenţa economică, dar şi politicodiplomatică, a României în spaţiul subsaharian s-a diminuat până la dispariţie în multe dintre statele odinioară finanţate şi susţinute politic de la Bucureşti. Această decizie politică asumată de guvernele care au condus România în perioada analizată a dus la pierderea pieţelor de desfacere, mai apoi a creanţelor, a influenţei regionale, a accesului la minereuri strategice şi hidrocarburi şi, în final, a puterii statale.

Aderarea României la UE şi Parteneriatul Strategic UE-Africa au marcat o revenire întrucâtva a prezenţei diplomatice şi a produselor româneşti pe pieţele subsahariene dar, mult sub nivelul atins în perioada regimului comunist, când România a deţinut, pentru prima dată în istoria sa, statutul de jucător geostrategic activ într-un spaţiu situat în afara propriilor frontiere, în speţă în Africa Subsahariană.

Trebuie amintit că piaţa subsahariană actuală, în creştere demografică şi economică, este extrem de atractivă pentru puteri industriale, precum China, India, Franţa, Federaţia Rusă, Australia, S.U.A., Israel sau Japonia, care au dezvoltat parteneriate pe multiple planuri cu statele subsahariene, preluând atât direcţii de acţiune utilizate de politica românească în regiune, în perioada premergătoare evenimentelor din 1989, cât şi pieţele deţinute de companiile româneşti. Atractivitate economică generată de competiţia pentru controlul surselor de minereuri strategice, materiile prime ale actualelor şi viitoarelor revoluţii industriale, dar şi de o serie de particularităţi ale acestor pieţe, mai puţin sensibile la criteriile de calitate, dar foarte sensibile la criteriile de preţ, criterii la care China şi India se califică fără probleme. Criterii la care s-ar fi calificat şi România dacă, în loc să îşi distrugă mare parte din patrimoniul industrial, alegea să retehnologizeze măcar o parte a acestuia.

Din păcate, dezangajarea diplomatică, schimbarea profilului economiei naţionale, provocările economice globale consecutive crizei medicale generate de virusul SARS-CoV-2, precum şi instabilitatea din anumite regiuni ale subcontinentului, continuă să menţină un nivel scăzut al prezenţei produselor româneşti în pieţele subsahariene. Situaţie puţin probabil a se schimba în viitorul apropiat sau mediu şi care va duce la pierderea totală a influenţei câştigate cu efort financiar uriaş în perioada comunistă, o dată cu dispariţia biologică a generaţiilor de intelectuali africani educaţi în şcolile şi universităţile româneşti, înainte de 31 decembrie 1989.

\section{BIBLIOGRAFIE:}

1. ***, „Pe urma miliardelor pierdute ale României socialiste, investite în afară", România Military, 26.04.2012, URL: http://www.rumaniamilitary.ro/peurma-miliardelor-pierdute-ale-romaniei-socialiste-investite-în-afara 
2. ***, ,Peştii, armele şi spionii. Ce legătură este între flota românească de pescuit, războaiele din Africa şi căderea lui Ceauşescu", ProTV, 28.09.2014, URL: http://stirileprotv.ro/emisiuni/2014/sezonul-2/pestii-armele-şi-spionii-ce-legaturaeste-între-flota-romaneasca-de-pescuit-razboaiele-din-africa-şi-caderea-luiceauşescu.html

3. ***, ,România are de recuperat creante de 1.472 mld. dolari, din 15 state”, Wall Street, 12.03.2007, URL: https://www.wall-street.ro/articol/Economie/26511/ Romania-are-de-recuperat-creante-de-1-472-mld-dolari-din-15-state.html

4. ***, „TOGO”, CIA - The World Factbook, URL: https://www.cia.gov/ library/publications/the-world-factbook/geos/to.html

5. ***, Raport privind creanţele României la 31 iunie 2005, provenite din activitatea de export, cooperarea economică internațională și alte acțiuni externe, derulate inainte de 31 decembrie 1989, Ministerul Finanțelor Publice, 28.06.2006, URL: http://www.cdep.ro/bperm/2006/F26954-creante.pdf

6. ***, Relaţii bilaterale Republica Africa de Sud, Direcţia Orientul Mijlociu şi Africa, Ministerul Afacerilor Externe, URL: http://www.mae.ro/bilateralrelations/1772\#746

7. ***, Relaţii bilaterale Republica Angola, Direcţia Orientul Mijlociu şi Africa, Ministerul Afacerilor Externe, URL: http://www.mae.ro/bilateralrelations/1809\#699

8. ***, Relaţii bilaterale Republica Federală Democratică a Etiopiei, Direcţia Orientul Mijlociu şi Africa, Ministerul Afacerilor Externe, URL: http://www.mae. ro/bilateral-relations/1854\#719

9. ***, Relaţii bilaterale Republică Sudan, Direcţia Orientul Mijlociu şi Africa, Ministerul Afacerilor Externe, URL: http://www.mae.ro/bilateralrelations $/ 1767 \# 747$

10. ***, The Africa-EU Partnership, URL: http://www.africa-eu-partnership. org/en/about-us/what-partnership

11. ***, Tradiţia relaţiilor româno-africane, Direcţia Orientul Mijlociu şi Africa, Ministerul Afacerilor Externe, Bucureşti, 2009.

12. COMAN, N., De la Atlantic la Oceanul Indian. Insemnările unui biolog din prima expediție românească trans-africană (1970-1971), Editura Dacia, Cluj-Napoca, 1975.

13. DINU, M., „Unele considerente referitoare la extinderea relaţiilor României cu statele din Africa, Asia, America Latină şi Orientul Mijlociu în a doua jumătate a secolului XX", URL: http://www.irsea.ro/Rela--355-ii-externe-secolul-XX/

14. Direcţia Orientul Mijlociu şi Africa, Ministerul Afacerilor Externe, URL: http://www.mae.ro/bilateral-relations/1772\#746

15. ILARION ȚIU, I., „Republica Africa Centrală, la picioarele lui Ceauşescu”, Historia, URL: https://www.historia.ro/secţiune/general/articol/republica-africa- 
centrală-la-picioarele-lui-ceauşescu

16. IONAŞCU, D., „Aici sunt banii dumneavoastră. Miliarde de dolari, risipite de România prin investiții în alte țări”, Libertatea, 01.07.2018, URL: https://www. libertatea.ro/stiri/aici-sunt-banii-dumneavoastra-miliarde-de-dolari-risipite-deromania-prin-investitii-alte-tari-2312134

17. MELINESCU, N., Uriaşul care se trezeşte, Volumul 2, CA Publishing, Bucureşti, 2009.

18. POPESCU, A.I.C., Jucătorul din umbră, Editura Militară, Bucureşti, 2016.

19. ZĂRNESCU, N., ,Întreprinderea de Pescuit Oceanic - unicat al industriei alimentare din economia socialistă", Linia Întâi, 23.10.2013, URL: http://inia1.ro/ întreprinderea-de-pescuit-oceanic-unicat-al-industriei-alimentare-din-economiasocialista/ 